\title{
JNVESTGAATONN
}

\section{The effect of using a vegetable fat blend on some attributes of kashar cheese}

\author{
By Harun Kesenkaş, ${ }^{a, *}$ Nayil Dinkçia ${ }^{a}$ A. Kemal Seçkin ${ }^{b}$, \\ Özer Kinik ${ }^{a}$ and Siddik Gönç ${ }^{a}$
}

\author{
${ }^{a}$ Ege University Faculty of Agriculture Department of Dairy Technology \\ Bornova, Izmir, Turkey. \\ ${ }^{\mathrm{b}}$ Celal Bayar University Faculty of Engineering Department of Food Engineering \\ Manisa, Turkey. \\ * Corresponding author: harun.kesenkas@ege.edu.tr
}

\section{RESUMEN}

\begin{abstract}
Efecto del uso de mezclas de grasas vegetales en algunas propiedades del queso kashar.
\end{abstract}

El queso kashar fue producido con leche entera (MF) o con leche desnatada homogenizada con una mezcla de grasas vegetales comercial (VF) por el método tradicional. Los quesos resultantes fueron almacenados durante 3 meses a $5^{\circ} \mathrm{C}$, y analizados para determinar su composición y su contenido en colesterol. Se estudió, además de la proteólisis y la lipolisis, el contenido de ácidos orgánicos y la composición en ácidos grasos durante la maduración de los quesos. La sustitución de la grasa de la leche por mezclas de grasas vegetales afectó principalmente al pH, sólidos totales y contenido de colesterol en la composición inicial de los quesos $(p<0.05)$. El grado de acidez y el contenido de tirosina en ambos quesos creció durante el proceso de maduración y diferencias significativas fueron encontradas entre ambos queso solo después de 30 días de maduración $(p<0.05)$. Las concentraciones de ácidos orgánicos de ambos quesos cambiaron durante la maduración $(p<0.05)$ excepto para los ácidos cítrico y oxálico. Los quesos MF mostraron un mayor contenido de ácidos cítrico, succínico y oxálico especialmente al final del proceso de maduración. $\mathrm{E}$ ácido palmítico fue el ácido graso mayoritario en quesos MF, mientras que los ácidos grasos predominantes en los quesos VF fueron el ácido palmítico y el ácido oleico. Además, el mayor contenido en ácidos grasos poliinsaturados en quesos VF los hace más atractivos desde un punto de vista nutricional.

PALABRAS CLAVE: Ácidos grasos - Ácidos Orgánicos Colesterol - Grasa vegetal - Queso Kashar

\section{SUMMARY}

The effect of using vegetable fat blend on some attributes of kashar cheese.

Kashar cheese was produced from whole milk (MF) or skim milk homogenized with a commercial vegetable fat blend (VF) by the traditional procedure. The resulting cheese was stored for 3 months at $5^{\circ} \mathrm{C}$, and analyzed initially for its gross composition and cholesterol content. In addition, the proteolysis and lipolysis, organic acid content and fatty acid composition were studied during the ripening of the cheese.
The replacement of milk fat with a vegetable fat blend mainly affected $\mathrm{pH}$, total solids and cholesterol content in the initial composition of the cheese $(P<0.05)$. The acid degree value and tyrosine contents in both types of cheese increased throughout ripening and significant differences were found between the cheeses after only 30 days of ripening $(P<0.05)$. The organic acid concentrations of both cheeses changed during ripening $(P<0.05)$ except for citric and oxalic acids. MF cheese showed higher levels of citric, succinic and oxalic acids especially towards to the end of ripening. Palmitic acid was the dominant fatty acid in MF cheese while the most abundant fatty acids in VF cheese were palmitic and oleic acid. The higher unsaturated fatty acid composition of the VF cheese has attracted attention from the healthy food image point of view.

KEY-WORDS: Cholesterol - Fatty acid - Kashar cheese - Organic acid - Vegetable fat.

\section{INTRODUCTION}

Since the 1980s, the eating habits of consumers have changed and they have become increasingly aware of the importance of maintaining adequate nutrition (Muir et al., 1999; Bachmann, 2001; Kavas et al., 2004). Thus many consumers limit their cheese consumption because of health-related concerns about milk fat's saturated fatty acid and cholesterol content, which is a major component in most cheese types (Yu and Hammond, 2000). In response to this trend, the dairy industry has reduced the fat content in cheeses or developed new products and so, definitions of "cheese analogues, cheese substitutes and cheese imitations" came into being (Yu and Hammond, 2000; Bachmann, 2001). Another driving force behind these new products is cost reduction which is so important for the production of fast foods like pizza (Muir et al., 1999; Bachmann, 2001).

Moreover, in recent years, cheese products wherein the butterfat is replaced with vegetable fat blends have gained increased popularity. Different procedures with hydrogenated vegetable oils such 
as soybean, peanut, palm kernel, cotton seed, coconut or corn were developed (Bachmann, 2001).

The triglyceride compositions of these fat blends have been designed to match both the consistency requirements and the important taste development of the cheese during ripening. This way it is possible to produce a vegetable fat-based cheese with a taste and texture that is very close to the milk fat equivalent.

Kashar cheese, the subject of this study, is a semi-hard traditional cheese which is one of the most consumed cheeses in Turkey and its production amounts to 45,730 tons/year (Özdemir and Demirci, 2006). It is produced from either sheep or cow's milk, or a mixture of both, and shows similarities with other types of cheese such as Caciocavallo, Provolone, Regusono, Kashkaval and partially with the Pasta Filata type cheese such as Mozzarella (Oksuz et al., 2001; Cetinkaya and Özütemiz, 2006). In recent years some studies were carried out to investigate the affects of protein and/or carbohydrate based fat replacers on low fat Turkish cheeses (Kavas et al., 2004; Koca and Metin, 2004). However the possibility of substituting milk fat with vegetable based fats in Turkish kashar cheese has not been explored extensively. Therefore the objective of this study was to determine the effects of the replacement of milk fat with a commercial vegetable fat blend on chemical properties, organic contents and fatty acid profiles of Turkish kashar cheese.

\section{MATERIALS AND METHODS}

\subsection{Cheese Production}

Kashar cheese production was carried out in a commercial dairy company (Koyuncuoglu, Torbali, Izmir). First, a vegetable fat blend (Karlshamns AB, Sweden) was added (3.10\%, v/v) to skim cow's milk (VF). This milk was heated and homogenized at 55$60^{\circ} \mathrm{C}$ and 120 bars respectively. Then the milk was pasteurized at $60^{\circ} \mathrm{C}$ for 20 minutes, cooled to $32^{\circ} \mathrm{C}$ and $0.02 \% \mathrm{CaCl}_{2}$ added. At this temperature double strength rennet extract (Maxiren 180, DSM Food Specialties, Istanbul, Turkey) was used as the clotting agent. The curds were milled at $\mathrm{pH} 5.90$ and then heated for $10-15$ minutes at $39^{\circ} \mathrm{C}$. The mild curds were then salted with $\mathrm{NaCl}(400 \mathrm{~g} / 40 \mathrm{~kg})$ and trisodium citrate $(300 \mathrm{~g} / 40 \mathrm{~kg})$ (DSM Food Specialties, Istanbul, Turkey) at $\mathrm{pH}$ 5.10. The curds were heated in a kettle of $50 \mathrm{~kg}$ capacity, using indirect steam injection at $85-90^{\circ} \mathrm{C}$ for 15 minutes. The hot product was hooped and pressed overnight at ambient temperature in 1-1.5 kg rectangular loaves. After pressing, cheeses were sealed into barrier film pouches and stored at $5^{\circ} \mathrm{C}$ for 3 months. Control cheese (MF) was also produced from cow's milk containing $3.05 \%$ milk fat by the same process for comparison so two different kashar cheeses (VF and MF) were obtained.

\subsection{Chemical Analyses}

The total solids, fat, protein and salt contents of each sample were determined according to (Oysun 2001). The $\mathrm{pH}$ values were measured using a Hanna 210 pH-meter. Cholesterol was determined following the procedure described by Fletouris et al. (1998). The acid degree value was determined according to the method described by Renner (1993). The tyrosine contents were measured spectrophotometrically at $650 \mathrm{~nm}$ (Citti et al. 1963).

\section{Determination of organic acids by HPLC}

7 gram of kashar cheese were taken and $40 \mathrm{ml}$ mobile phase $\left(0.1 \% \mathrm{H}_{2} \mathrm{PO}_{4}\right)$ were added and mixed with an ultratorrax for 1 minute. The mixture was held in a water bath for 1 hour and than centrifuged at $6000 \mathrm{rpm}$ for 5 minutes. The upper phase was filtered through filter paper (Whatman No: 1). To obtain the calibration curves mixtures of standards of certain concentrations were also injected into HPLC and their chromatograms were obtained. A perkin Elmer Series 200 Model HPLC apparatus equipped with a UV absorbance detector set at 214 $\mathrm{nm}$ was used. Chromatographic separation was performed on a Shodex RSpak KC-118 model ionexchange organic column $(8 \times 300 \mathrm{~mm}$ i.d. $)$.

\section{Lipid extraction and preparation of fatty acid methyl esters}

Lipids were extracted with purified kieselguhr and diethyl ether as described by Renner (1993). Fatty acid methyl esters were prepared according to AOAC (1997). Sample (approximately $200 \mathrm{mg}$ ) was weighed accurately into a glass centrifuge vial with a stopper and $2 \mathrm{ml}$ of hexane were added, followed by $0.1 \mathrm{ml}$ of $2 \mathrm{gL}^{-1}$ methanolic $\mathrm{KOH}$. Then the vial was closed, shaken well for $30 \mathrm{~s}$, and centrifuged. Two drops of the upper layer were removed and diluted with $2.0 \mathrm{ml}$ of hexane. The sample was injected into capillary column GC analysis using split injection.

\section{Determination of fatty acid composition by gas chromatography}

The instrumentation used for the analyses was as follows: a Hewlett-Packard GC (model 6890) equipped with Supelco SP-2380 fused silica capillary column $(60 \mathrm{~m} \times 0.25 \mathrm{~mm}$ i.d., $0.2 \mu \mathrm{m}$ film thickness; Supelco Inc., Bellefonte, PA, USA) and a flame ionization detector. The injection volume was $2 \mu \mathrm{l}$. The temperature of GC oven was programmed from 100 to $220^{\circ} \mathrm{C}$ at the rate of $4^{\circ} \mathrm{C}$ $\mathrm{min}^{-1}$. The injector and detector temperatures were $300^{\circ} \mathrm{C}$. Nitrogen was used as the carrier gas and the flow rate was $1 \mathrm{ml} / \mathrm{min}$. The split ratio was set at $1: 100$. 


\subsection{Statistical Analysis}

One way analysis of variance (ANOVA) was applied and whenever it was adequate Duncan's Multiple Range Test was used in order to determine the differences between VF and MF cheeses. Also the effect of ripening on cheeses was subjected to this same analysis using SPSS $^{\odot} 9.05$ statistical package (SPSS Inc., Chicago, USA). In all cases 0.05 probability level was considered and both cheeses were produced in triplicate.

\section{RESULTS AND DISCUSSION}

\subsection{Chemical Composition}

The chemical characteristics of the fresh kashar cheeses at the first day of production are shown in Table 1. Although the total solid contents of the cheeses were very similar, statistically lower results were found in kashar cheese made with the vegetable fat blend $(P<0.05)$. The fat in total solids contents of both cheeses did not significantly differ and met the Turkish legal specifications (Anonymous, 1999) of a minimum of $45 \%$ for full fat kashar cheese. Also these results are similar to industrially made kashar cheese (Katsiari et al., 2002; Van Nieuwenhove et al., 2007). There were no significant differences in protein or salt contents between the MF and VF cheeses.

The $\mathrm{pH}$ value was lower in VF than MF cheese, this difference was found statistically significant $(P<0.05)$. This can be attributed to the high free fatty acid contents of the vegetable fat blend (During et al. 2000). However both $\mathrm{pH}$ values are adequate for cheese to maintain its quality during ripening as mentioned by some researchers (Georgala et al., 2005; Van Nieuwenhove et al., 2007).

As expected, the cholesterol level in kashar cheese containing milk fat was significantly higher $(P<0.05)$ because its main source of cholesterol is animal fat. It is clear that the cholesterol observed in vegetable fat added samples was almost zero but

Table 1

Gross composition and cholesterol content of the cheese

\begin{tabular}{lcc}
\hline & MF & VF \\
\hline Total Solids \% & $52.97 \pm 0.1 \mathrm{a}$ & $51.49 \pm 0.25 \mathrm{~b}$ \\
\hline Fat \% & $26.06 \pm 0.42$ & $25.17 \pm 1.61$ \\
\hline Fat in Total Solids \% & $49.19 \pm 0.88$ & $48.89 \pm 3.31$ \\
\hline Protein \% & $19.52 \pm 1.45$ & $19.47 \pm 0.31$ \\
\hline Salt \% & $2.38 \pm 0.34$ & $2.46 \pm 0.12$ \\
\hline pH & $5.85 \pm 0 \mathrm{a}$ & $5.60 \pm 0 \mathrm{~b}$ \\
\hline Cholesterol mg $/ 100 \mathrm{~g}$ & $56.60 \pm 1.76 \mathrm{a}$ & $0.49 \pm 0.01 \mathrm{~b}$ \\
\hline a, b Means within the same row without a common superscript \\
are significantly different $(P<0.05)$.
\end{tabular}

the content of $0.49 \mathrm{mg} / 100 \mathrm{~g}$ could be originated from milk serum. Also the cholesterol contents in MF cheese were found to be lower than those of Kinik et al. (2005) in fresh kashar cheese.

\subsection{Lipolysis and Proteolysis}

The acid degree value (ADV) refers to measurements of the amount of free fatty acids presents in a fat sample which is a quantitative index of hydrolytic lipolysis in dairy products (Park and Lee, 2006). The ADV increased continuously during the ripening period only in MF cheeses (Table 2.) $(P<0.05)$ and a significant difference was found between cheese samples only after 30 days of ripening. The ADVs reached their maximum after 90 days for MF cheese and after 60 days for VF cheese. These results indicate that the rate and extent of lipolysis in both cheeses was quite similar and that they are lower than the results reported by Tarakci and Kucukoner (2006) and Sahan et al. (2007), but higher than those reported by (Kaminarides and Stachtiaris 2000) on soybean oil added Kasseri cheese.

Table 2

Acid degree value (ADV) (meq KOH kg-1) and tyrosine $\left(\mathrm{mg} \mathrm{g}^{-1}\right)$ contents of the cheese during ripening

\begin{tabular}{lccc}
\hline Cheese & Days & ADV & Tyrosine \\
\hline MF & 1 & $1.28 \pm 0.19 \mathrm{a}$ & $0.13 \pm 0.02 \mathrm{a}$ \\
& 30 & $1.31 \pm 0.07 \mathrm{a} \mathrm{X}$ & $0.15 \pm 0.01 \mathrm{a} \mathrm{X}$ \\
& 60 & $1.65 \pm 0.23 \mathrm{ab}$ & $0.21 \pm 0.01 \mathrm{~b}$ \\
& 90 & $1.99 \pm 0.41 \mathrm{~b}$ & $0.36 \pm 0.06 \mathrm{c}$ \\
\hline VF & 1 & $1.19 \pm 0.02 \mathrm{a}$ & $0.12 \pm 0 \mathrm{a}$ \\
& 30 & $1.76 \pm 0.26 \mathrm{~b} \mathrm{Y}$ & $0.20 \pm 0.01 \mathrm{~b} \mathrm{Y}$ \\
& 60 & $2.22 \pm 0.5 \mathrm{~b}$ & $0.24 \pm 0.02 \mathrm{~b}$ \\
& 90 & $1.70 \pm 0.02 \mathrm{ab}$ & $0.36 \pm 0.03 \mathrm{c}$ \\
\hline
\end{tabular}

a, b, c Means in the same column with different superscripts within cheese type are significantly different $(P<0.05)$.

$X, Y$ Means in a column and at the same age with different superscripts are significantly different $(P<0.05)$.

The tyrosine based spectrophotometric tests detect released $\alpha$-amino groups which result from the proteolysis of milk proteins, thus giving a direct measurement of proteolytic activity. As shown in Table 2 the tyrosine content in the cheeses increased progressively and was more intense after 3 months $(P<0.05)$. This may be due to the action of heat resistant proteinases and some probable contaminated non-starter bacteria which are principally responsible for the formation of small size peptides (Fox, 1993). In general, the cheese made with vegetable fat had a higher level of tyrosine contents; especially after 30 days $(P<0.05)$. In the present study the soluble tyrosine ranged from $0.12-0.36 \mathrm{mg} \mathrm{g}^{-1}$ cheese while the reported values for ripened Kashkaval cheese were an average of $0.036 \mathrm{mg} \mathrm{g}^{-1}$ cheese (Simov and 
Ivanov, 2005). Also the soluble tyrosine content of the soft and hard cheeses ranged from 2.29-2.66 and 2.16-2.92 $\mathrm{mg} \mathrm{g}^{-1}$ with an average of 2.44 and $2.81 \mathrm{mg} \mathrm{g}^{-1}$ as reported by Abd-El Salam et al. (1979), Fernández-Salguero and Sanjuán (1999), Madadlou et al. (2007) respectively.

\subsection{Organic Acids}

The main organic acids in the kashar cheeses throughout ripening were lactic, citric, acetic, propionic, butyric, succinic, oratic and oxalic acid. The effects of the addition of the vegetable fat blend and ripening on the organic acid content of both cheeses are presented in Table 3. The effect of ripening was significant $(P<0.05)$ for all organic acids except citric acid. The oxalic acid content was not affected in MF cheese throughout ripening. Only the oxalic, citric and succinic acid content differences between samples were significant $(P<0.05)$ mainly toward to the end of ripening.

Citric acid was the abundant acid detected in both cheese samples. Nevertheless the concentration of citric acid in cheese samples showed a different trend and its final concentration was higher in MF cheese $(P<0.05)$. Citrate in milk is metabolized by many lactic acid bacteria into flavor components such as acetate, acetaldehyde and diacetyl (Buffa et al., 2004). The higher amount of citric acid found in cheeses could be attributed to citrate in emulsifying salt.

Lactic acid is the second abundant acid detected in kashar cheeses and its initial concentration was found to be 220.13 and $240.69 \mathrm{mg} \mathrm{kg}^{-1}$ for VF and MF samples respectively. The concentration of lactic acid increased continuously $(P<0.05)$ during ripening mainly as a result of the fermentation of lactose by thermotolerant bacteria. The ratio of lactic acid produced is essential for assuring the good quality and proper ripening process of cheeses (Califano and Bevilacqua, 2000). An analogous trend was observed during the ripening of the different types of cheese (Bouzas et al., 1991; Zeppa et al., 2001; Akalin et al., 2002).
Acetic acid is considered a product of several biochemical pathways, such as the fermentation of lactate and citrate or the metabolism of amino acids by bacteria. It contributes highly to the final flavor of cheese types especially feta cheese (Buffa et al., 2004; Abd El-Salam and Alichanidis, 2004; Manolaki et al., 2006). The acetic acid contents of both cheese samples was increased as the cheeses aged up to day $60(P<0.05)$ (Table 3$)$. Many scientists have stated that the concentration of acetic acid in different cheese types such as Feta, Cheddar, Provolone, Blue, Emmental, Halloumi, Ossolono, Beaufort and Monterey Jack ranged from 0.13 to $7.10 \mathrm{mg} \mathrm{g}^{-1}$ cheese (Bevilacqua and Califano, 1992; Buffa et al., 2004; Park and Lee, 2004; Manolaki et al., 2006; Kaminarides et al., 2007).

Propionic acid was detected in small amounts in kashar cheeses. The concentration of propionic acid showed a dramatic drop after day 30 , followed by a more moderate level. Then it remained at the same concentration in MF cheese and was not detectable for the rest of ripening in VF cheese. According to the literature, propionic acid can range from 0.16 to $0.60 \mathrm{mg} \mathrm{g}^{-1}$ in different cheese types. (Bouzas et al., 1991; Lues and Botha, 1998).

The succinic acid content decreased slightly until day 30 of ripening, but then remained stable and increased throughout the ripening period $(P<0.05)$. Certain strains of Lactobacillus produce or consume succinic acid as reported by Ocando et al. (1993) and Manolaki, et al. (2006). In addition, significant differences were found between samples after 60 days of ripening $(P<0.05)$. This can be attributed to the variation in catabolic reactions.

The butyric acid present in kashar cheeses MF and VF were initially found to be 0.05 and $0.08 \mathrm{mg}$ $\mathrm{g}^{-1}$ respectively. Moreover, during the ripening period the concentration of butyric acid increased continuously $(P<0.05)$. The values found for butyric acid were in agreement with those reported by Katsiari et al. (2000), Park and Lee (2006). An increase in the concentration of butyric acid during ripening was reported for feta cheese by Georgala

Table 3

Organic acid concentrations $\left(\mathrm{mg} \mathrm{kg}^{-1}\right)$ in the cheese during ripening

\begin{tabular}{cccccccccc}
\hline Cheese & Days & $\begin{array}{c}\text { Citric } \\
\text { Acid }\end{array}$ & $\begin{array}{c}\text { Lactic } \\
\text { Acid }\end{array}$ & $\begin{array}{c}\text { Acetic } \\
\text { Acid }\end{array}$ & $\begin{array}{c}\text { Propionic } \\
\text { Acid }\end{array}$ & $\begin{array}{c}\text { Succinic } \\
\text { Acid }\end{array}$ & $\begin{array}{c}\text { Butyric } \\
\text { Acid }\end{array}$ & $\begin{array}{c}\text { Oratic } \\
\text { Acid }\end{array}$ & $\begin{array}{c}\text { Oxalic } \\
\text { Acid }\end{array}$ \\
\hline MF & 1 & $357.65 \pm 26.81$ & $240.69 \pm 23.47 \mathrm{a}$ & $0.65 \pm 0.08 \mathrm{a}$ & $2.91 \pm 0.59 \mathrm{~b}$ & $3.57 \pm 0.51 \mathrm{ab}$ & $0.05 \pm 0.08 \mathrm{a}$ & $0.78 \pm 0.11 \mathrm{a}$ & $3.17 \pm 0.41$ \\
& 30 & $339.38 \pm 32.09$ & $246.56 \pm 26.80 \mathrm{a}$ & $2.67 \pm 0.26 \mathrm{~b}$ & $0.99 \pm 0.88 \mathrm{a}$ & $3.09 \pm 0.57 \mathrm{a}$ & $2.17 \pm 0.39 \mathrm{~b}$ & $1.30 \pm 0.17 \mathrm{a}$ & $2.99 \pm 0.30 \mathrm{X}$ \\
& 60 & $345.53 \pm 20.55$ & $293.15 \pm 11.04 \mathrm{~b}$ & $3.34 \pm 0.38 \mathrm{c}$ & $1.21 \pm 0.22 \mathrm{a}$ & $4.33 \pm 0.08 \mathrm{~b} \mathrm{X}$ & $4.81 \pm 0.11 \mathrm{c}$ & $2.08 \pm 0.58 \mathrm{~b}$ & $2.84 \pm 0.09 \mathrm{X}$ \\
& 90 & $392.93 \pm 12.88 \mathrm{X}$ & $317.07 \pm 17.96 \mathrm{~b}$ & $3.04 \pm 0.44 \mathrm{bc}$ & $0.37 \pm 0.57 \mathrm{a}$ & $6.97 \pm 0.53 \mathrm{cX}$ & $8.20 \pm 0.89 \mathrm{~d}$ & $3.15 \pm 0.44 \mathrm{c}$ & $3.17 \pm 0.04 \mathrm{X}$ \\
\hline VF & 1 & $347.48 \pm 17.63$ & $220.13 \pm 10.71 \mathrm{a}$ & $1.08 \pm 0.43 \mathrm{a}$ & $3.21 \pm 0.22 \mathrm{~b}$ & $3.51 \pm 0.57 \mathrm{a}$ & $0.08 \pm 0.08 \mathrm{a}$ & $0.71 \pm 0.05 \mathrm{a}$ & $2.63 \pm 0.42 \mathrm{~b}$ \\
& 30 & $342.10 \pm 8.81$ & $253.25 \pm 27.51 \mathrm{ab}$ & $2.75 \pm 0.44 \mathrm{~b}$ & $0.98 \pm 0.14 \mathrm{a}$ & $3.26 \pm 0.23 \mathrm{a}$ & $2.33 \pm 0.20 \mathrm{~b}$ & $1.43 \pm 0.18 \mathrm{ab}$ & $2.07 \pm 0.11 \mathrm{a} Y$ \\
& 60 & $324.65 \pm 29.47$ & $319.27 \pm 54.90 \mathrm{bc}$ & $2.92 \pm 0.40 \mathrm{~b}$ & $0.83 \pm 0.16 \mathrm{a}$ & $3.52 \pm 0.32 \mathrm{a} Y$ & $4.70 \pm 0.16 \mathrm{c}$ & $1.78 \pm 0.39 \mathrm{~b}$ & $1.94 \pm 0.18 \mathrm{a} Y$ \\
& 90 & $326.32 \pm 21.38 \mathrm{Y}$ & $382.94 \pm 69.52 \mathrm{c}$ & $2.72 \pm 1.20 \mathrm{~b}$ & n.d. & $5.07 \pm 0.57 \mathrm{~b}$ Y & $8.73 \pm 0.48 \mathrm{~d}$ & $2.85 \pm 0.97 \mathrm{c}$ & $1.77 \pm 0.23 \mathrm{a} \mathrm{Y}$ \\
\hline
\end{tabular}

$\mathrm{a}, \mathrm{b}, \mathrm{c}$ Means in the same column with different superscripts within cheese type are significantly different $(P<0.05)$.

$X, Y$ Means in a column and at the same age with different superscripts are significantly different $(P<0.05)$. 
et al. (2005), Akalin et al., (2002), Manolaki et al. (2006) and for goat's milk cheese by (Park and Lee 2006) and for raw pasteurized or high pressure treated goat's milk cheese by Buffa et al. (2004).

Oratic acid concentrations increased in different amounts as ripening progressed $(P<0.05)$. The reason for high concentrations of oratic acid in cheese could be attributed to non starter microbial enzymes and rennet activity which facilitate more extensive biochemical reactions (Lues and Botha, 1998). Bouzas et al. (1991), Akalin et al. (2002), Manolaki et al. (2006), Park and Lee (2006) working with different cheese types reported variable results for oratic acid.

Oxalic acid present in fresh and aged cheese was at notably higher concentrations. The initial content of oxalic acid in VF cheese was gradually decreased $(P<0.05)$ with refrigerated ageing. On the other hand the levels of oxalic acid in MF cheese showed irregular changes with a slight tendency to decrease until day 60 and increased afterwards. Highly different results were reported for the oxalic acid content in Cheddar and Ossalano cheese (Lues and Botha, 1998; Zeppa et al., 2001).

It can be said that the organic acid quantities and profiles obtained for kashar cheese could presumably be ascribed to 1) additives used during production 2) the influence of curd heating on the biochemical composition and 3 ) the action of contaminating microflora during the ripening of the product.

\subsection{Fatty Acid Composition}

The free fatty acid (FFA) profile of both cheeses is shown in Table 4. The results assembled in the table indicate that the fatty acid patterns of both cheeses were not changed during ripening. Although kashar samples containing milk fat and vegetable fat showed quite different fatty acids patterns, palmitic (C16:0) and oleic acids (C18:1) were the most abundant FFA in both cheeses at all sampling ages. Milk fat is the only fat known to contain butyric acid (C4:0) (Walstra and Jenness, 1984). Therefore, its content in cheese samples was taken as an index of milk fat percentage in cheese fat (Calvo et al. 2007). The low percentage of butyric acid in the VF samples could be attributed to its production from skim milk which also led to a low cholesterol content.

As seen from the table, the short-chain fatty acid (SCFA, C4:0-C12:0) and medium-chain fatty acid (MCFA, C14:0-C16:1) contents of the MF cheese were higher than VF cheese but the difference in SCFA was definitely higher. The key property at this point is the importance of SCFAs for the flavor development in cheese because of their low perception threshold. Moreover, when SCFA concentrations are high in Kashar cheese, flavor intensity increased but flavor quality could vary (Guler, 2005). The concentration of myristic acid (C14:0) in the MF cheese was higher than that in the VF cheese and was the most effective fatty acid in the difference between MCFAs. With respect to long-chain fatty acids (LCFA, $\geq$ C18:0), the oleic acid (C18:1) concentration was higher in VF cheese (C18:2) than in MF cheese followed by linoleic acid whereas the stearic acid (C18:0) concentration was lower. These fatty acids have a higher perception threshold and are thought to play a less important role in cheese flavor.

Table 4

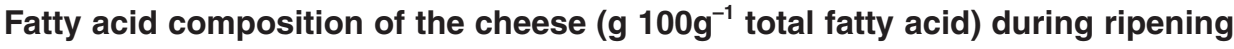

\begin{tabular}{|c|c|c|c|c|c|c|c|c|}
\hline & \multicolumn{2}{|c|}{$1^{\text {st }}$ day } & \multicolumn{2}{|c|}{$30^{\text {th }}$ day } & \multicolumn{2}{|c|}{$60^{\text {th }}$ day } & \multicolumn{2}{|c|}{$90^{\text {th }}$ day } \\
\hline & MF & VF & MF & VF & MF & VF & MF & VF \\
\hline C4:0 & $2.30 \pm 0.07$ & $0.28 \pm 0.01$ & $2.30 \pm 0.07$ & $0.25 \pm 0.01$ & $2.33 \pm 0.10$ & $0.28 \pm 0.02$ & $2.33 \pm 0.05$ & $0.30 \pm 0.10$ \\
\hline C6:0 & $1.73 \pm 0.03$ & $0.26 \pm 0.01$ & $1.74 \pm 0.04$ & $0.25 \pm 0.02$ & $1.73 \pm 0.09$ & $0.25 \pm 0.02$ & $1.73 \pm 0.01$ & $0.27 \pm 0.03$ \\
\hline C8:0 & $1.11 \pm 0.01$ & $0.15 \pm 0.01$ & $1.10 \pm 0.02$ & $0.14 \pm 0.01$ & $1.11 \pm 0.03$ & $0.15 \pm 0.01$ & $1.10 \pm 0.00$ & $0.17 \pm 0.03$ \\
\hline C10:0 & $2.53 \pm 0.02$ & $0.34 \pm 0.01$ & $2.53 \pm 0.0$ & $0.31 \pm 0.01$ & $2.49 \pm 0.10$ & $0.33 \pm 0.01$ & $2.53 \pm 0.01$ & $0.38 \pm 0.02$ \\
\hline & $3.09 \pm 0.01$ & $0.63 \pm 0.02$ & $3.07 \pm 0.03$ & $0.59 \pm 0.02$ & $3.05 \pm 0.13$ & $0.62 \pm 0.02$ & $3.09 \pm 0.01$ & \\
\hline C14 & $11.28 \pm 0.03$ & $2.26 \pm 0.04$ & $11.27 \pm 0.02$ & $2.18 \pm 0.04$ & $11.21 \pm 0.36$ & $2.29 \pm 0.04$ & $11.25 \pm 0.01$ & 0.02 \\
\hline C14:1 & & & & & $1.06 \pm 0$ & & $1.10 \pm 0.00$ & $0.15 \pm 0.00$ \\
\hline C16:0 & $32.34 \pm 0.03$ & $37.32 \pm 0.59$ & $32.32 \pm 0.18$ & $38.66 \pm 0.84$ & $33.41 \pm 1.31$ & $39.43 \pm 0.11$ & $32.36 \pm 0.12$ & $39.83 \pm 0.02$ \\
\hline C16:1 & $1.55 \pm 0.01$ & $0.26 \pm 0.08$ & $1.59 \pm 0.01$ & $0.32 \pm 0.01$ & $1.51 \pm 0.09$ & $0.34 \pm 0.01$ & $1.57 \pm 0.01$ & $0.38 \pm 0.03$ \\
\hline C18:0 & $11.22 \pm 0.14$ & $4.64 \pm 0.30$ & $11.08 \pm 0.05$ & $6.57 \pm 0.53$ & $11.55 \pm 0.76$ & $7.31 \pm 0.87$ & $11.12 \pm 0.08$ & $7.68 \pm 0.01$ \\
\hline C18:1 & $24.87 \pm 0.13$ & $39.94 \pm 1.59$ & $25.12 \pm 0.01$ & $39.66 \pm 0.35$ & $24.25 \pm 0.81$ & $39.29 \pm 0.77$ & $25.43 \pm 0.19$ & $39.55 \pm 0.10$ \\
\hline C18:2 & $2.29 \pm 0.03$ & $10.50 \pm 0.32$ & $2.33 \pm 0.04$ & $7.43 \pm 1.42$ & $2.15 \pm 0.12$ & $8.18 \pm 0.07$ & $2.44 \pm 0.03$ & $3 \pm 0.02$ \\
\hline Others & $3.2 \pm 0.26$ & $3.1 \pm 1.53$ & $3.65 \pm 0.63$ & $3.91 \pm 3.06$ & $3.17 \pm 0.16$ & $1.58 \pm 0.54$ & $2.78 \pm 0.37$ & $0.81 \pm 0.21$ \\
\hline & & & & & & & & \\
\hline MCFA & $47.76 \pm 0.30$ & $40.72 \pm 0.24$ & $48.03 \pm 0.21$ & $41.83 \pm 0.80$ & $48.90 \pm 0.99$ & $42.50 \pm 0.26$ & $47.85 \pm 0.15$ & $42.97 \pm 0.10$ \\
\hline LCFA & $39.80 \pm 0.26$ & $57.38 \pm 2.70$ & $40.14 \pm 0.60$ & $56.96 \pm 3.82$ & $38.39 \pm 0.46$ & $56.00 \pm 0.57$ & $39.90 \pm 0.18$ & $56.04 \pm 0.13$ \\
\hline PUFA & $2.95 \pm 0.09$ & $11.88 \pm 1.88$ & $3.36 \pm 0.64$ & $10.27 \pm 3.95$ & $2.58 \pm 0.11$ & $9.06 \pm 0.42$ & $2.79 \pm 0.02$ & $8.73 \pm 0.17$ \\
\hline MUFA & $28.51 \pm 0.05$ & $41.30 \pm 1.48$ & $28.65 \pm 0.02$ & $40.65 \pm 0.33$ & $27.82 \pm 0.83$ & $40.16 \pm 0.65$ & $28.86 \pm 0.10$ & $40.31 \pm 0.05$ \\
\hline SFA & $67.14 \pm 0.26$ & $46.63 \pm 0.53$ & $67.22 \pm 0.08$ & $49.49 \pm 1.31$ & $68.64 \pm 1.25$ & $50.94 \pm 1.01$ & $67.17 \pm 0.11$ & $51.82 \pm 0.27$ \\
\hline
\end{tabular}

SCFA: short-chain fatty acids, MCFA: medium-chain fatty acids, LCFA: Long-chain fatty acids, SFA: saturated fatty acids,

MUFA: monounsaturated fatty acids, PUFA: polyunsaturated fatty acids. 
The addition of vegetable fat blends to cheese would change its saturated/unsaturated acid ratio in particular, along with its polyunsaturated fatty acid (PUFA) contents (Calvo et al. 2007). As seen from Table 4, the PUFA and MUFA contents in VF cheese were higher but the SCFA content was lower than that in MF cheese. The high content of PUFA in our study suggests that the vegetable fat used in the production of kashar cheese compromised the nutritional value of the cheese. Higher contents of unsaturated fatty acids are perceived to be healthier than saturated fatty acids (Zhang et al., 2006) because of their positive effects mainly in the prevention of cardiovascular disease and cancer (Calvo et al., 2007).

\section{CONCLUSIONS}

The replacement of milk fat with a vegetable fat blend in Kashar cheese did not markedly changed the gross composition of the samples. The tyrosine levels in both samples increased steadily during the ripening stage $(P<0.05)$. Citric acid was the abundant organic acid that was detected in both cheese samples mainly at the beginning of ripening. The butyric acid levels for both cheeses were increased continuously and markedly during ripening. The cholesterol level of the VF samples was very low. As a result of FFA analysis, the fatty acid patterns of both cheeses were not changed during ripening. The short and medium chain fatty acid contents of the MF were higher than the VF cheese. In addition, the SFA level of the MF samples was higher than the VF samples. At the same time, the MUFA contents of the VF samples were higher. These results are very important with respect to the prevention of atherosclerosis, cardiovascular diseases and elevated blood pressure. So the production of Kashar cheese with a vegetable fat blend may have a significant impact on human nutrition.

\section{REFERENCES}

Abd El-Salam MH, Alichanidis E. 2004. Cheese varieties ripened in brine $\left(3^{\text {rd }}\right.$ ed.). In: P.F. Fox, P.L.H. McSweeney, T.M. Cogan, T.P. Guinee, Editors, Cheese: chemistry, physics and microbiology Vol. 2, Elsevier, Amsterdam, pp. 227-249.

Abd El-Salam MH, Mohamed A, Ayad E, Fahmy N, El Shibiny S. 1979. Changes in the quality and chemical composition of ras cheese by some commercial enzyme preparations. Egypt Journal of Dairy Science 7, 63-74.

Akalin AS, Gonc S, Akbas Y. 2002. Variation in organic acids content during ripening of pickled white cheese. Journal of Dairy Science 85, 1670-1676.

Anonymous, 1999. Turkish standard kashar cheese TS 3272, TSE, Bakanliklar, Ankara.

AOAC 1997. Association of Official Analytical Chemists, Official Method Ce 2-66, 1-2.

Bachmann HP. 2001. Cheese analogues: a review. International Dairy Journal 11, 505-515.
Bevilacqua AE, Califano AN. 1992. Changes in organic acids during ripening of port salut Argentino cheese. Food Chemistry 43, 345-349.

Bouzas J, Kantt CA, Bodyfelt F, Torres JA. 1991. Simultaneous determination of sugars and organic acids in cheddar cheese by high-performance liquid chromatography. Journal of Food Science 56, 276278.

Buffa M, Buenaventura G, Saldo J, Trujillo AJ. 2004 Changes in organic acids during ripening of cheeses made from raw, pasteurized or high-pressure-treated goats' milk. Lebensmittel-Wissenschaft und-Technologie 37, 247-253.

Califano AN, Bevilacqua AE. 2000. Multivariate analysis of the organic acids content of gouda type cheese during ripening. Journal of Food Composition and Analysis 13, 949-960.

Calvo MV, Juarez M, Fontecha J, El-Aasar M, Naguib M, Abd El-Salam MH. 2007. Effect of milk fat replacement with vegetable oils on fatty acids composition and conjugated linoleic acid content of market Egyptian processed cheeses. Egyptian Journal of Dairy Science 35, 97-108.

Cetinkaya F, Özütemiz GE. 2006. Microbiological and chemical changes throughout the manufacture and ripening of kashar: a traditional Turkish cheese. Turkish Journal of Veterinary and Animal Sciences 27, 791-787.

Citti JE, Sandine WE, Elliker PR. 1963. Some observations on the hull method for measurement of proteolysis in milk. Journal of Dairy Science 46, 337.

During A, Mazette S, Combe N, Entressangles B. 2000. Lipolysis and oxidative stability of soft ripened cheeses containing vegetable oils. Journal of Dairy Research 67, 461-468.

Fernández-Salguero J, Sanjuán E. 1999. Influence of vegetable and animal rennet on proteolysis during ripening in ewes' milk cheese. Food Chemistry 64, 177-183.

Fletouris DJ, Botsoglou NA, Psomas IE, Mantis AI. 1998. Rapid determination of cholesterol in milk and milk products by direct saponification and capillary gas chromatography, Journal of Dairy Science 81, 28332840.

Fox PF. 1993. Cheese: Chemistry, physics and microbiology. ( $2^{\text {nd }}$ ed.). London, U.K. Chapman and Hall, pp.439.

Georgala A, Moschopoulou E, Aktypis A, Massouras T, Zoidou E, Kandarakis I, Anifantakis E. 2005. Evolution of lipolysis during the ripening of traditional Feta cheese. Food Chemistry 93, 73-80.

Guler Z. 2005. Quantification of free fatty acids and flavor properties in Kasar Cheeses. Journal of Food Lipids 12, 209-221.

Kaminarides S, Stachtiaris S. 2000. Production of processed cheese using Kasseri cheese and processed cheese analogues incorporating whey protein concentrate and soybean oil. International Journal of Dairy Technology 53, 69-74.

Kaminarides S, Stamou P, Massouras T. 2007. Changes of organic acids, volatile aroma compounds and sensory characteristics of Halloumi cheese kept in brine, Food Chemistry 100, 219-225.

Katsiari MC, Voutsinas LP, Kondyli E. 2002. Improvement of sensory quality of low-fat Kefalograviera-type cheese with commercial adjunct culture. International Dairy Journal 12, 757-764.

Katsiari MC, Voutsinas LP, Alichandis E, Roussis IG. 2000. Proteolysis in reduced sodium Feta cheese 
made by partial replacement of $\mathrm{NaCl}$ by $\mathrm{KCl}$. International Dairy Journal 10, 635-646.

Kavas G, Oysun G, Kinik O, Uysal H. 2004. Effect of some fat replacers on chemical, physical and sensory attributes of low fat white pickled cheese. Food Chemistry 88, 381-383.

Kinik O, Gursoy O, Seckin AK. 2005. Cholesterol content and fatty acid composition of most consumed Turkish hard and soft cheeses. Czech Journal Of Food Sciences 23, 166-172.

Koca N, Metin M. 2004. Textural, melting and sensory properties of low fat fresh kashar cheeses produced by using fat replacers. International Dairy Journal 14, 365-373.

Lues JFR, Botha WC. 1998. Relationships amongst South African processed, young and matured Cheddar cheese pertaining to organic acid content and non-starter population. Food Research International 31, 449-457.

Madadlou A, Khosrowshahiasl A, Mousavi ME, Farmani J. 2007. The influence of brine concentration on chemical composition and texture of Iranian White cheese, Journal of Food Engineering 81, 330-335.

Manolaki P, Katsiari MC, Alichanidis E. 2006. Effect of a commercial adjunct culture on organic acid contents of low-fat Feta-type cheese. Food Chemistry 98, 658-663.

Muir DD, Tamime AY, Shenana ME, Dawood AH. 1999. Processed cheese analogues incorporating fatsubstitutes 1. Composition, microbiological quality and flavour changes during storage at $5^{\circ} \mathrm{C}$. Lebensmittel Wissenschaft und Technologie 32, 41-49.

Ocando A, Granados A, Lasanta Y, Gutierrez B, Cabrera L. 1993. Organic acids of low molecular weight produced by lactobacilli and enterococci isolate from Palmita type Venezuelan cheeses, Food Microbiology 10, 1-7.

Oksuz O, Kurultay S, Simsek O. 2001. The effect of Brevibacterium linens on some physico-chemical properties and colour intensity of Kashar cheese. Milchwissenschaft 56, 82-85.

Oysun G. 2001. Analysis Methods of Milk Products, Faculty of Agriculture, Ege University, publication no: 504. Izmir, Turkey.

Ozdemir C, Demirci M. 2006. Selected microbiological properties of kashar cheese samples preserved with potassium sorbate. International Journal of Food Properties 9, 515-521.

Park Y, Lee J. 2006. Effect of freezing on organic acid contents and lipolytic index of plain soft and Monterey Jack goat milk cheeses. Small Ruminant Research 63, 58-65.

Renner E. 1993. Milchpraktikum Skriptum zu den Übüngen. Justus Liebig Universitat, Giesen, Germany.

Sahan N, Yasar K, Hayaloglu AA, Karaca OB, Kaya A. 2007. Influence of fat replacers on chemical composition, proteolysis, texture profiles, meltability and sensory properties of low-fat Kashar cheese. Journal of Dairy Research 75, 1-7.

Simov ZI, Ivanov GY. 2005. Proteolytic activity of Lactobacillus delbrueckii ssp. bulgaricus and streptococcus thermophilus in frozen-stored Kashkaval cheese. Journal of Industrial Microbiology and Biotechnology 32, 449-454.

Tarakci Z, Kucukoner E. 2006. The changes on physicochemical, lipolysis and proteolysis of vacuumpacked Kashar Cheese. Journal of Central European Agriculture 7, 459-464.

Van Nieuwenhove CP, Oliszewski R, Gonzalez SN, Chaia ABP. 2007. Influence of bacteria used as adjunct culture and sunflower oil addition on conjugated linoleic acid content in buffalo cheese, Food Research International 40, 559-564.

Walstra P, Jenness R. 1984. Dairy Chemistry and Physics, Wiley, New York.

Yu L, Hammond EG. 2000. The modification and analysis of vegetable oil for cheese making. Journal of the American Oil Chemists' Society 77, 911-916.

Zeppa G, Conterno L, Gerbi V. 2001. Determination of organic acids, sugars, diacetyl, and acetoin in cheese by high-performance liquid chromatography. Journal of Agricultural and Food Chemistry 47, 2722 -2726.

Zhang RH, Mustafa AF, Ng-Kwai-Hang KF, Zhao X. 2006. Effects of freezing on composition and fatty acid profiles of sheep milk and cheese. Small Ruminant Research 64, 203-210. 